\title{
Examination of the Physical and Motoric Characteristics of Elite Soccer Players According to Their Positions
}

\author{
Duygu Aksoy ${ }^{1} \&$ Baris Baydemir ${ }^{2}$ \\ ${ }^{1}$ School of Physical Education and Sports, Namık Kemal University, Tekirdag, Turkey \\ ${ }^{2}$ Faculty of Sport Sciences, Canakkale Onsekiz Mart University, Canakkale, Turkey \\ Correspondence: Baris Baydemir, Faculty of Sport Sciences, Canakkale Onsekiz Mart University, Canakkale, \\ Turkey. E-mail: barisbaydemir@hotmail.com
}

Received: January 29, $2019 \quad$ Accepted: March 1, $2019 \quad$ Online Published: March 8, 2019

doi:10.5539/jel.v8n2p223

URL: https://doi.org/10.5539/jel.v8n2p223

This paper was poster presented at World Congress of Sport Sciences Researches held between 23-26 November, 2017 in Manisa.

\begin{abstract}
The purpose of the present study was to examine the physical and motoric characteristics of elite soccer players playing at different positions in U21 team. A total of 64 male soccer players participated in the present study (4 goalkeepers, 16 defense players, 21 midfield players, and 23 strikers). The Body Mass Indices of the players were computed by measuring their height and weights. The Yo-Yo Intermittent Recovery 2 Test and the t-test were applied to the players. The VO2max values of the players were computed according to the formula that was developed by Bangsbo et al. The statistical package programs were employed for data analyses. The "Independent Sampling One-Way Variance Analysis" was applied to compare the physical and motoric characteristics of elite soccer players according to their positions. When differences were detected between the measurements, the "Tukey Analysis" was carried out to determine the direction of these differences. The results were evaluated according to $(\mathrm{p}<0.05)$ significance level. It was determined that there was a statistically significant difference between the BMI values of elite soccer players according to their positions $(p<0.05)$. It was also determined that the motoric characteristics of the players did not have any significant differences according to their positions $(p>0.05)$. The lowest values were determined in goalkeepers, strikers, midfield players and defense players according to the BMI values of the elite soccer players. This situation might be associated with the fact that in today's soccer, players show performance in different areas of the field for attack and defense without considering their positions. According to the BMI values of the elite soccer players, the lowest values were determined in goalkeepers, strikers, midfield players and defense players; and no differences were detected in terms of motoric characteristics.
\end{abstract}

Keywords: training, quickness, soccer, t-test, Yo-Yo test

\section{Introduction}

Soccer is the most-preferred sports branch in terms of the pleasure of watching for masses. In soccer, although the duration of the game does not change, the increase in the workload on the players in this period is evaluated as the development in soccer with the improving technology. The physical and physiological effects of soccer on players and similar characteristics have been the topic of interest for researchers so far.

Soccer has different movements in its structure (jumps, head kicks, ball hits, sprints, etc.), which change rapidly. Running tempos define the speed of the game. In our present time, several methods like heart rate and lactate concentration measurements are employed as valid and objective approaches to predict the exercise load of players in physical activities. Soccer players move in different directions with different densities in soccer, and this makes it difficult to foresee the physiological loads on players. However, new technologies like portable heart rate monitors and lactate analyzers make it possible for researchers to analyze the requirements related to soccer in terms of the rate and the duration of energy expenditure (Eniseler, 2005).

It was observed that male midfield players covered the largest distances in a soccer game, and completed high-intensity activities in various positions (Bloomfield et al., 2007). Moreover, previous studies reported that 
midfield players had better performances in tests like the Yo-Yo Intermittent Recovery, and had bigger aerobic capacities and repetitive sprinting capabilities (Reilly et al., 2000; Mohr et al., 2003, Krusturp et al., 2006).

Soccer players run with a maximum heart rate of $80-90 \%$ in competitions, which is close to the anaerobic threshold. In a competition, in soccer players, the distance that was covered was $2-3 \mathrm{~km}$ in high-intensity activities $(>15 \mathrm{~km} / \mathrm{h})$, and sprint distances $(>20 \mathrm{~km} / \mathrm{h})$ were $600 \mathrm{~m}$ (Laia et al., 2009). Researchers determined that each player made short-term movements between 4-6 seconds for 1000-1400 times during a game, and that these movements occurred every 5-6 seconds, and there were breaks for 3 seconds every 2 minutes (Mohr et al., 2003; Reily, 2003; Strudwick et al., 2002). In the light of these data, it may be suggested that soccer is a game that includes both basic aerobic and anaerobic endurance systems and basic motoric characteristics like force, explosive force and speed (Pinasco \& Carson, 2005).

In soccer, players move in different positions as if they were locomotives, and change the direction of the game based on the position of the ball and their opponents. When players are performing the movements like changing the direction of the game, moving faster to the opponent goal post, the physical, physiological and technical differences among players in positions are the main reasons that disrupt the game flow in this process. Even if each player has the same position, they have different tasks in the game. However, today, in soccer, players are more involved in performance compared to technical training. There is the idea of helping the teammates outside the actual positions of the players as one of the main reasons for this. In this context, the present study was conducted to examine the physical and motoric characteristics of elite soccer players who played in different positions in elite $\mathrm{U} 21$ team.

\section{Material and Methods}

\subsection{Participants}

A total of 64 male soccer players who played in professional U21 team participated voluntarily in the present study (4 goalkeepers, 16 defense players, 21 midfield players, and 23 strikers). The ages of the soccer players were as follows: goalkeepers $20 \pm 0.98$; defense players $20 \pm 0.54$; midfield players $20 \pm 0.33$; strikers $20 \pm 0.12$. The heights of the players were as follows; goalkeepers 180.750 \pm 4.57 ; defense players $179.188 \pm 3.63$; midfield players $181.048 \pm 4.79$; strikers $181.565 \pm 3.51$. The weights of the players were as follows: goalkeepers $66.50 \pm 2.88$; defense players $70.93 \pm 3.12$; midfield players $71.57 \pm 3.99$; strikers $71.39 \pm 3.35$. The training experiences of the players were as follows; goalkeepers $7 \pm 1.21$; defense players $7 \pm 1.54$; midfield players $7 \pm 1.64$; strikers $7 \pm 1.87$.

\subsection{Procedures}

The players participated in training programs of 1.5 -hour a day. The season was divided into three training parts, as preparatory period, preliminary competition period and competition period. The players trained for 3 days a week during the season. They also played game 1 day a week. All the measurements were completed when the season ended. All measurements were made in between 8:00 and 12:00 a.m. in order to have similar chrono-biological characteristics (Drust et al., 2005). No trainings were applied to the players for 24 hours before the tests. All the measurements were completed in the same laboratory and training area. All the players were informed about the study and procedures. All the participants signed the informed consent form according to the Helsinki Declaration.

\subsection{Measurements}

\subsubsection{Measurements of Height and Body Weight}

The body height and weight measurements were made on bare feet by using a digital scale (Seca 664, Hamburg, Germany); and the players wore only a short.

\subsubsection{Body Mass Index (BMI)}

The Body Mass Indices (BMI) of the players was measured with the "kg/height ${ }^{2}(\mathrm{~m})$ " formula in $\mathrm{kg}$ (Williams \& Wilkins, 2000).

\subsubsection{Yo-Yo Intermittent Recovery 2 Test Protocol}

The method used in previous studies was employed in the present study. The Yo-Yo Intermittent Recovery 2 (IR2) Test was applied to the players in the soccer field (grass ground). The Yo-Yo Intermittent Recovery 2 is a maximum test of incremental speed controlled by an audio, in which the subjects had to perform $2 \times 20$ meters in a shuttle race. They had an active recovery period of 10 seconds, consisting of a shuttle run of $2 \times 5$ meters between stages. The test started at a speed of $13 \mathrm{~km} . \mathrm{h}^{-1}$, and increased by $2 \mathrm{~km} \mathrm{~h}^{-1}$ after the first stage and by 1 $\mathrm{km} \mathrm{h}^{-1}$ after the second stage, then continued increasing by $0.5 \mathrm{~km} \mathrm{~h}^{-1}$ after each stage until exhaustion. The test 
was completed at the time the player did not reach the finish line in the required time, twice consecutively, or when the player voluntarily stopped. If a participant did not complete a trial successfully, a score of 0 was given (Raya et al., 2013; Bradley et al., 2014; Ingebrigtsen et al., 2014).

The VO2max values of the players were computed according to the formula that was developed by Bangsbo and Iaia (2008).

$$
\mathrm{VO}_{2} \max (\mathrm{ml} / / \mathrm{min} / \mathrm{kg})=\mathrm{IR} 2 \text { distance }(\mathrm{m}) \mathrm{x} 0.0136+45.3 \text { (Bangsbo \& Iaia, 2008). }
$$

\subsubsection{The T-Test Protocol}

The t-test was applied to the players on the training field (grass ground). The players participated in the test with trainers. The t-test was administered using a version standardized from previous literature (Bloomfield et al., 2007; Williams \& Wilkins, 2000). The units of measurement were changed from yards to meters, creating a 10x10 m course. The course procedure of having the participant touch each cone is not standardized in the literature; therefore, the task was eliminated. The directions adopted for this study were based on Miller et al. With the "go" command, the participant (1) ran or moved as quickly as possible forward to the center cone, (2) sidestepped to the right $5 \mathrm{~m}$ to the right cone, (3) sidestepped to the left $10 \mathrm{~m}$ to the far-left cone, and then (1) sidestepped back to the right to the center cone. The participant ran or moved backward as quickly as possible to cross the finish line. The raters began the stop watch on "go" and stopped when the participant reached the plane of the finish line. The time to complete each trial was recorded in seconds. Disqualification was determined if the participant failed to run the course as instructed, failed to reach the finish line or complete the course, moved any cones, did not keep his body and feet pointed forward at all times, or crossed his legs more than once when sidestepping (Miller et al., 2006; Semenick, 1994). A two-gate photocell electronic chronometer (Tumer Elektronik Ltd., Turkey) was placed on the start and finish points of the test track with 1-meter distance between them. The test was repeated twice by applying the interval rules, and the best result was recorded (Thomas \& Williams, 2005).

\subsection{Statistical Analyses}

The statistical package programs were employed for data analyses. To compare the physical and motor characteristics of the elite soccer players according to their positions, the "Independent Sampling One-Way Variance Analysis" was applied. When there were differences, the "Tukey Analysis" was performed to see where the differences were. The results were evaluated according to $(\mathrm{p}<0.05)$ significance level.

\section{Results}

The findings of the present study that was conducted to determine whether the physical and motoric characteristics of soccer players differed according to their positions in the game are given below.

In the present study, in addition to the physical characteristics of the players like the age, height, Body Mass Indices, and motor characteristics; their agility and motoric characteristics like Yo-Yo, MaxVO2 and quickness are also given in Table 1. 
Table 1. The measurement values of the physical and motoric characteristics of the elite soccer players according to their positions

\begin{tabular}{lllll}
\hline Variables & Position & Lowest & Maximum & Average \pm SD \\
\hline Body weight $(\mathrm{kg})$ & Goalkeepers & 63.0 & 70.0 & $66.500 \pm 2.887$ \\
& Defense players & 63.0 & 75.0 & $70.938 \pm 3.129$ \\
& Midfield players & 65.0 & 80.0 & $71.571 \pm 3.995$ \\
Height $(\mathrm{cm})$ & Strikers & 65.0 & 77.0 & $71.391 \pm 3.354$ \\
& Goalkeepers & 175.0 & 186.0 & $180.750 \pm 4.574$ \\
& Defense players & 170.0 & 185.0 & $179.188 \pm 3.637$ \\
& Midfield players & 174.0 & 191.0 & $181.048 \pm 4.790$ \\
Body Mass Index $\left(\mathrm{kg} / \mathrm{m}^{2}\right)$ & Strikers & 174.0 & 188.0 & $181.565 \pm 3.514$ \\
& Goalkeepers & 19.9 & 20.7 & $20.350 \pm 0.369$ \\
& Defense players & 21.0 & 23.9 & $22.081 \pm 0.679$ \\
& Midfield players & 20.5 & 23.3 & $21.824 \pm 0.729$ \\
Yo-Yo Test & Strikers & 20.5 & 22.5 & $21.639 \pm 0.691$ \\
& Goalkeepers & 960.0 & 1320.0 & $1120.000 \pm 149.666$ \\
& Defense players & 840.0 & 2040.0 & $1230.000 \pm 307.853$ \\
& Midfield players & 880.0 & 2040.0 & $1300.952 \pm 298.361$ \\
& Strikers & 840.0 & 1560.0 & $1159.130 \pm 192.068$ \\
MaxVO $_{2}$ & Goalkeepers & 58.356 & 63.252 & $60.804 \pm 2.011$ \\
& Defense players & 56.724 & 73.044 & $62.059 \pm 4.137$ \\
& Midfield players & 57.268 & 73.044 & $62.964 \pm 4.047$ \\
& Strikers & 56.724 & 66.516 & $61.075 \pm 2.486$ \\
Quickness (Seconds) $^{*}$ & Goalkeepers & 7.56 & 8.13 & $7.813 \pm 0.252$ \\
& Defense players & 7.50 & 8.60 & $8.044 \pm 0.335$ \\
& Midfield players & 6.70 & 8.50 & $7.888 \pm 0.405$ \\
& Strikers & 6.70 & 8.79 & $7.685 \pm 0.496$ \\
\hline
\end{tabular}

According to One-Way Analysis of Variance, it was found that there were no statistically significant differences between the motoric characteristics of the soccer players (Yo-Yo test, MaxVO2 and quickness), and their heights and weights according to their positions ( $p>0.05$ ). It was also determined in the present study that Body Mass Index values of the players had statistically significant differences between them according to their positions $(p<0.05)$. The results obtained in this context are given in Table 2 .

Table 2. Independent sampling one-way variance analysis (ANOVA)

\begin{tabular}{|c|c|c|c|c|c|c|}
\hline Variables & Groups & $\begin{array}{l}\text { Degree of } \\
\text { Freedom }\end{array}$ & Sum of Squares & Average of Squares & $\mathrm{F}$ & $\mathrm{p}$ \\
\hline \multirow[t]{3}{*}{ Yoyo Test } & Inter group & 3 & 264380.189 & 88126.730 & 1.296 & 0.284 \\
\hline & Intragroup (mistakes) & 60 & 4080763.561 & 68012.726 & & \\
\hline & Total & 63 & 4345143.750 & & & \\
\hline \multirow[t]{3}{*}{$\mathrm{MaxVO}_{2}$} & Inter group & 3 & 44.624 & 14.875 & 1.219 & 0.311 \\
\hline & Intragroup (mistakes) & 60 & 732.349 & 12.206 & & \\
\hline & Total & 63 & 776.974 & & & \\
\hline \multirow[t]{3}{*}{ Quickness (Second) } & Inter group & 3 & 1.257 & 0.419 & 2.380 & 0.079 \\
\hline & Intragroup (mistakes) & 60 & 10.568 & 0.176 & & \\
\hline & Total & 63 & 11.826 & & & \\
\hline \multirow[t]{3}{*}{ Height $(\mathrm{cm})$} & Inter group & 3 & 56.208 & 18.736 & 1.133 & 0.343 \\
\hline & Intragroup (mistakes) & 60 & 991.792 & 16.530 & & \\
\hline & Total & 63 & 1048.000 & & & \\
\hline \multirow[t]{3}{*}{ Weight (kg) } & Inter group & & 91.379 & 30.460 & 2.475 & 0.070 \\
\hline & Intragroup (mistakes) & 3 & 738.559 & 12.309 & & \\
\hline & Total & 60 & 829.938 & & & \\
\hline \multirow[t]{3}{*}{ Body Mass Index $\left(\mathrm{kg} / \mathrm{m}^{2}\right)$} & Inter group & 63 & 9.966 & 3.322 & 7.002 & 0.000 \\
\hline & Intragroup (mistakes) & 3 & 28.467 & 0.474 & & \\
\hline & Total & 60 & 38.434 & & & \\
\hline
\end{tabular}


In the present study, the Tukey Test was carried out to find the cause of the differences in the Body Mass Indices. According to the Tukey Analysis, significant differences were detected between goalkeepers and midfield players, goalkeepers and defense players, and goalkeepers and strikers against goalkeepers $(\mathrm{p}<0.05)$ in terms of Body Mass Indices. The results obtained in this context are given in Table 3.

Table 3. Multiple comparisons test (Tukey)

\begin{tabular}{lllll}
\hline Positions & & Average Difference & Standard Error & $\mathrm{p}$ \\
\hline Goalkeeper & Defense player & $-1.731^{*}$ & 0.385 & 0.000 \\
& Midfield player & $-1.474^{*}$ & 0.376 & 0.001 \\
& Striker & $-1.289^{*}$ & 0.373 & 0.005 \\
Defense player & Goalkeeper & $1.731^{*}$ & 0.385 & 0.000 \\
& Midfield player & 0.257 & 0.229 & 0.675 \\
& Striker & 0.442 & 0.224 & 0.210 \\
Midfield player & Goalkeeper & $1.474^{*}$ & 0.376 & 0.001 \\
& Defense player & -0.257 & 0.229 & 0.675 \\
Striker & Striker & 0.185 & 0.208 & 0.811 \\
& Goalkeeper & $1.289^{*}$ & 0.373 & 0.005 \\
& Defense player & -0.442 & 0.224 & 0.210 \\
& Midfield player & -0.185 & 0.208 & 0.811 \\
\hline
\end{tabular}

The present study was conducted to determine whether the physical and selected motoric characteristics of elite soccer players differed according to their positions. As a result of the present study, it was determined that the heights of the elite soccer players were as follows; goalkeepers $66.50 \pm 2.88$; defense players $70.93 \pm 3.12$; midfield players $71.57 \pm 3.99$; strikers $71.39 \pm 3.35$. The heights of the players were as follows; goalkeepers $180.750 \pm 4.57$; defense players $179.188 \pm 3.63$; midfield players $181.048 \pm 4.79$; strikers $181.565 \pm 3.51$. The BMI values of the players were as follows; goalkeepers $20.350 \pm 0.36$, defense players $22.081 \pm 0.67$, midfield players $21.824 \pm 0.72$, strikers $21.639 \pm 0.69 \pm 3.51) \mathrm{kg} / \mathrm{m}^{2}$, Yo-Yo Intermittent Recovery 2 Test results were as follows; goalkeepers $1120.00 \pm 149.66$, defense players $1230.00 \pm 307.85$, midfield players $1300.95 \pm 298.36$, strikers $1159.13 \pm 192.06 \mathrm{~m} ; \mathrm{MaxVO}_{2}$ values were as follows; goalkeepers $60.80 \pm 2.01$, defense players $62.05 \pm 4.13$, midfield players $62.96 \pm 4.04$, strikers, $61.07 \pm 2.48 \mathrm{ml} . \mathrm{kg} \cdot \mathrm{min}^{-1}$, quickness values were as follows; goalkeepers $7.81 \pm 0.25$, defense players $8.04 \pm 0.33$, midfield players $7.88 \pm 0.40$, strikers, $7.68 \pm 0.49$ seconds.

According to the BMI values of the elite soccer players, the lowest values were determined in goalkeepers, strikers, midfield players and defense players; and it was determined that there were no differences in terms of the motoric characteristics. When the literature was examined, it was determined that there are studies reporting overlapping and controversial results with the results of the present study.

\section{Discussion}

Sporis et al. conducted a study with 270 soccer players and compared them according to their positions (goalkeepers, defense players, midfield and attack players). As a result of their study, they reported that goalkeepers were the tallest and heaviest players in the team; the best players were the attack players according to $5,10,20-\mathrm{m}$ speed performances, goalkeepers were the best players according to explosive force (crouching, jumping) performances, and that the midfield players had the highest values according to oxygen consumption, heart rate, and maximum running speeds when compared to defense and attack players (Sporis et al., 2009).

Gjonbalaj et al. conducted a study and reported that defense players had higher body weights than midfield players at a statistically significant level; and that there were no statistically significant differences among the other anthropometric measurements, the somatotype components in the players playing in different positions in the team (Gionbalai et al., 2018).

By using the Yo-Yo Intermittent Recovery 1 test, Castagna et al. reported that the scores of the attack players were good, and those of the defense players were slightly lower (Castagna et al., 2006).

In the study conducted by Taskin, it was determined that there were no statistically significant differences between the positions of players and body weights, heights and $30 \mathrm{~m}$ sprint values of defense, midfield and attack players according to their positions (Taskin, 2006).

In the study conducted by Doner with 75 players, although there were significant differences between height and body weight values of the players according to their positions, there were no significant differences between 
their ages and Body Mass Indices. In addition, in the same study, it was reported that the mean heights of the goalkeepers were more than those of the midfield players, the average heights of the attack players were more than those of the defense and midfield players, and the body weights of the midfield players were lower at a significant level than those in other positions (Doner, 2011).

Cerrah et al. conducted a study with 89 amateur soccer players, and determined that there were no significant differences among the body fat ratios and Body Mass Indices, $10 \mathrm{~m}$ and $30 \mathrm{~m}$ sprint values, and leg strength and vertical jump degrees in terms of the positions of the players (Cerrah et al., 2011).

In the study conducted by Koc and Aslan, the average vertical jump of 70 soccer players was $58.49 \pm 6.40 \mathrm{~cm}$, leg strength was $126.51 \pm 17.82 \mathrm{~kg}$, sprint value of $10 \mathrm{~m}$ was $1.77 \pm 0.12 \mathrm{sec}, 30 \mathrm{~m}$ sprint value was $4.30 \pm 0.18 \mathrm{sec}$, anaerobic power was $119.07 \pm 18.50 \mathrm{~kg} / \mathrm{sec}$, flexibility value was $27.81 \pm 6.14 \mathrm{~cm}, 20 \mathrm{~m}$ shuttle run average was $94.19 \pm 17.71$ and $\mathrm{MaxVO} 2$ average was $50.01 \pm 5.2 \mathrm{ml} . \mathrm{kg} . \mathrm{min}^{-1}$. When the players were compared according to their positions, it was determined that statistically significant differences were detected in heights, body weights and lean body masses. It was determined that stoppers were determined to be taller compared to side players, strikers compared to side and back players, and goalkeepers compared to side and back players. In addition, it was also determined that according to the $10 \mathrm{~m}$ and $30 \mathrm{~m}$ sprint degrees of the players, the highest values were measured in side players, and the lowest scores were measured in stoppers and goalkeepers; and in terms of MaxVO2 capacity, side players had the highest values, and strikers had the lowest values (Aslan \& Koc, 2015).

In their study, Erdem et al. compared 44 amateur players who played in different positions according to BMI, balance, agility test with and without ball. According to the results they obtained, there were significant differences between the positions of soccer players in terms of BMI values. The BMI values of the defense players were lower than those of the midfield and attack players (Erdem et al., 2015).

Nalbant et al. conducted a study and reported that goalkeepers, stoppers and strikers had parallel heights, and the heights of midfield players were lower. It was determined that there were no differences between the positions according to the heights, weights and BMI values of the players (Nalbant et al., 2017).

In the study conducted by Cometti et al., some motoric and physiological characteristics of players were compared according to their positions. It was determined that the heights were in favor of goalkeepers and defense players, the goalkeepers and defense players, and midfield players and strikers; and the weights were in favor of goalkeepers and defense players, defense players and midfield players (Cometti et al., 2001).

\section{Conclusions}

According to the BMI values of the elite soccer players, the lowest values were determined in goalkeepers, strikers, midfield players and defense players; and it was also determined that there were no differences according to motoric characteristics. Although positional differences were faced more in former years; nowadays, the changing format of soccer requires that players play closer to each other. In today's soccer, players can be considered as performing in different parts of the field for attacks and defenses without considering fixed positions. The present study may be considered as a reference for future studies that will be conducted. Elite female soccer players may be included in a future study that will be conducted with a broader sampling.

\section{References}

Aslan, C. S., \& Koç, H. (2015). Comparing Selected Physical and Motoric Characteristics of Turkish Amateur Soccer Players According to Playing Positions. CBÜ Beden Egitimi ve Spor Bilimleri Dergisi, 10(1), 56-65.

Bangsbo, J. (2003). Physiology of Training. In T. Reilly \& A. Williams (Eds.), Science and Soccer (vol. 13, pp. 47-58). London: Routledge.

Bangsbo, J., Iaia, F. M., \& Krustrup, P. (2008). The Yo-Yo intermittent recovery test. Sports Medicine, 38(1), 37-51. https://doi.org/10.2165/00007256-200838010-00004

Bloomfield, J., Polman, R., \& O’Donoghue, P. (2007). Physical demands of different positions in FA Premier League soccer. Journal of Sports Science \& Medicine, 6(1), 63.

Bradley, P. S., Bendiksen, M., Dellal, A., Mohr, M., Wilkie, A., Datson, N., \& Krustrup, P. (2014). The Application of the Yo_Yo Intermittent Endurance Level 2 Test to Elite Female Soccer Populations. Scandinavian Journal of Medicine and Science in Sports, 24(1), 43-54. https://doi.org/10.1111/j.1600-0838.2012.01483.x

Castagna, C., Chamari, K., Impellizzerri, M. F., \& Carlomogno, D. (2006). Aerobic Fitness and Yo-Yo Continuous and Intermittent Tests Performances in Soccer Players: Acarrelation Study. The Journal of Strength and Conditioning Research, 20(2), 320-325. https://doi.org/10.1519/00124278-200605000-00015 
Cerrah, A. O., Polat, C., \& Ertan, H. (2011). Examination of some physical and technical parameters of Super Amateur League soccer players. Nigde Üniversitesi Beden Egitimi ve Spor Bilimleri Dergisi, 5(1), 1-6.

Cometti, G., Maffiuletti, N. A., \& Pousson, M. (2001). Isokinetic Strenght and Anaerobik Power of elite, Subelite and Amateur French Soccer Players. International Journal Sports Medicine, 22, 45-51. https://doi.org/10.1055/s-2001-11331

Döner, H. (2011). Determination of somatotype characteristics of soccer players according to their positions (Diyarbakır case). PhD thesis, Selçuk University Institute of Health Sciences.

Drust, B., Waterhouse, J., Atkinson, G., Edwards, B., \& Reilly, T. (2005). Circadian rhythms in sports $\begin{array}{llll}\text { performance-An update. } & \text { Chronobiology }\end{array}$ https://doi.org/10.1081/CBI-200041039

Eniseler, N. (2005). Heart rate and blood lactate concentrations as predictors of physiological load on elite soccer players during various soccer training activities. Journal of Strength and Conditioning Research, 19(4), 799.

Erdem, K., Çaglayan, A., Korkmaz, O., Bozdogan, T., \& Ozbar, N. (2015). The Evaluation of Body Mass Index, Balance and Agility Features of Amateur Soccer Players According to Their Positions. Uluslararasi Spor, Egzersiz ve Antrenman Bilimi Dergisi, 1(2), 95-103.

Gjonbalaj, M., Georgiev, G., \& Bjelica, D. (2018). Differences in Anthropometric Characteristics, Somatotype Components, and Functional Abilities Among Young Elite Kosovo Soccer Players Based on Team Position. International Journal of Morphology, 36(1).

Ingebrigtsen, J., Brochmann, M., Castagna, C., Bradley, P. S., Ade, J., Krustrup, P., \& Holtermann, A. (2014). Relationships between field performance tests in high-level soccer players. Journal of Strength and Conditioning Research, 28(4), 942-949. https://doi.org/10.1519/JSC.0b013e3182a1f861

Krustrup, P., Mohr, M., Nybo, L., Jensen, J. M., Nielsen, J. J., \& Bangsbo, J. (2006). The Yo-Yo IR2 test: physiological response, reliability, and application to elite soccer. Medicine \& Science in Sports \& Exercise, 38(9), 1666-1673. https://doi.org/10.1249/01.mss.0000227538.20799.08

Laia, F. M., Rampinini, E., \& Bongsbo, J. (2009). High-Intensity Training in Soccer. International Journal of Sports Physiology and Performance, 4, 291-306. https://doi.org/10.1123/ijspp.4.3.291

Miller, M. G., Herniman, J. J., Ricard, M. D., Cheatham, C. C., \& Michael, T. J. (2006). The effects of a 6-week plyometric training program on agility. Journal of Sports Science and Medicine, 5(3), 459-465.

Mohr, M., Krustrup, P., \& Bongsbo, J. (2003). Match Performance of High-Standard Soccer Players with Special Reference to Development of Fatigue. Journal of Sports Sciences, 21, 519-528. https://doi.org/10.1080/0264041031000071182

Nalbant, Ö., Gözen, O., Özbek, M., \& Erceylan, C. (2017). Evaluation of Physical and Contitioning Features Acording to Position in Soccer. Istanbul Üniversitesi Spor Bilimleri Dergisi, 7(2), 38-49.

Pinasco, A., \& Carson, J. (2005). Preseason conditioning for college soccer. Strength and Conditioning Journal, 27, 56-62. https://doi.org/10.1519/00126548-200510000-00009

Raya, A. M., Gailey, S. R., Gaunaurd, A. I., Jayne, M. D., Campbell, M. S., Gagne, E., Manrique, G. P., Muller, G. D., \& Tucker, C. (2013). Comparison of three agility tests with male servicemembers: Edgren Side Step Test, T-Test, and Illinois Agility Test. Journal of Rehabilitation Research and Development, 50(7), 951-960. https://doi.org/10.1682/JRRD.2012.05.0096

Reilly, T. (2003). Motion Analysis and Physiological Demands, In T. Reilly \& A. Williams (Eds.), Science and Soccer (pp. 59-72). London: E \& FN Spon. https://doi.org/10.4324/9780203417553

Reilly, T., Bangsbo, J., \& Franks, A. (2000). Anthropometric and physiological predispositions for elite soccer. Journal of Sports Sciences, 18(9), 669-683. https://doi.org/10.1080/02640410050120050

Semenick, D. (1994). Testing protocols and procedures. In T. Baechle (Ed.), Essentials of strength training and conditioning (1st ed., pp. 258-273). Champaign (IL): Human Kinetics.

Sporis, G., Jukic, I., Ostojic, S. M., \& Milanovic, D. (2009). Fitness profiling in soccer: physical and physiologic characteristics of elite players. The Journal of Strength \& Conditioning Research, 23(7), 1947-1953. https://doi.org/10.1519/JSC.0b013e3181b3e141 
Strudwick, A., Reilly, T., \& Doran, D. (2002). Anthropometric and Fitness Profiles of Elite Players in Two Soccer Codes. Journal of Sports Medicine and Physical Fitness, 42(2).

Taskın, H. (2006). Investigation Some Physical Parameters and 30 Meter Sprint Capabilities of Professional Soccer Players According to Their Playing Positions. Spormetre Beden Eğitimi ve Spor Bilimleri Dergisi, $4(2), 49-54$.

Thomas, L., \& Williams, A. (2005). Specificity of acceleration, maximum speed and agility in Professional soccer players. In T. Relliy, J. Cabrii \& A. Duarte (Eds.), Science and soccer (pp. 276-283). London: Routledge.

Williams, L., \& Wilkins, M. A. (2000). ACSM's guidelines for exercise testing and prescription (6th ed.), American College of Sports Medicine, USA.

\section{Copyrights}

Copyright for this article is retained by the author, with first publication rights granted to the journal.

This is an open-access article distributed under the terms and conditions of the Creative Commons Attribution license (http://creativecommons.org/licenses/by/4.0/). 